\title{
Agricultural Ecosystem: An Encouraging Field for Ornithologists
}

\section{Narayan Ramappa Birasal ${ }^{*}$}

KLE Society's Gudleppa Hallikeri College, Haveri, India

Agricultural ecosystem is open system, whereby continuous human intervention is needed for the maintenance of equilibrium with the aim of maximizing the production provided by a few domesticated plant and animal species. In these systems, the equilibrium is maintained through energy input from outside that makes the operations possible, which are designed to create optimal conditions for the growth of the cultivated plants and the animals raised. Ecology and management of birds in agricultural ecosystems deals with all activities of birds that are either beneficial or harmful to mankind [1].

Agricultural landscapes, especially in the intensively cultivated areas have a number of fish, dairy, poultry and honeybee farms interspersed among crop fields. These farms along with a variety of native and exotic agroforestry trees provide additional food to birds in the form of fish, bees, animal feeds, tree-fruits, seeds, nectar etc. Birds of agricultural areas hence include granivores, frugivores, insectivores, carnivores, nectarivores and omnivores. The Sarus crane has survived the landscape of Gujarat due to cultural heritage of the local people and ability of the species to track habitat changes [2].

Many pristine natural environments are constantly being modified by human activities. Such modifications of natural landscapes result in the formation of many new landscapes such as cultivated agricultural landscape which is almost a new landscape and differs in many important respects from natural ecosystems. As the field is prepared using traditional bullock driven plough, a large number of birds follow it and pick up insects, earthworms etc. which are exposed (Figures 1and 2). There exists no quantitative information on the extent of control brought about by birds during ploughing operations and the benefits gained thereby [3].

Agricultural ecosystems are young on an evolutionary time scale even where agriculture has been practiced continuously for more than 4000 years as in the case of rice cultivation in India, Thailand and Southern China. Thus, agriculture represents an enormous unplanned experiment on how biodiversity responds to environmental change. The presence of breeding species is related to characteristics of boundaries and to the surrounding land-use. The management of hedgerows and other field boundaries is narrated in detail to encourage the presence of breeding birds [4].

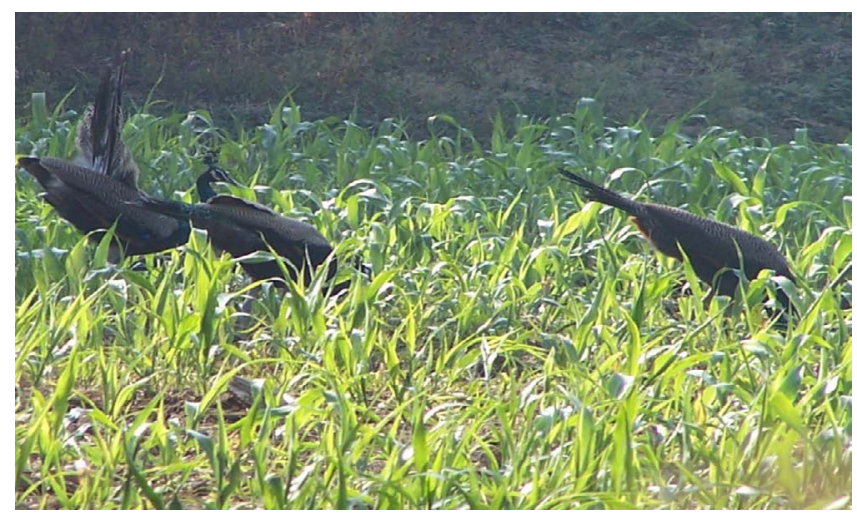

Figure 1: Indian national birds-Peacocks feeding in the maize field.

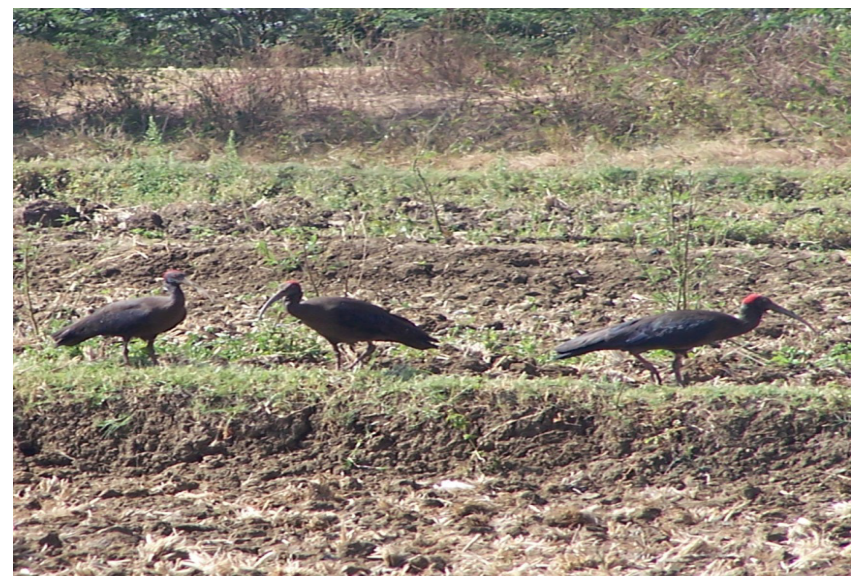

Figure 2: Black ibises found in the farmland habitat.

Many bird species have shown population declines in farmland habitats across Britain and Europe in recent decades. Recent changes in agricultural practice are said to be likely causes of these declines [5]. Indeed, agricultural landscapes are excellent models for studying the relationships between biodiversity and the habitat template and the importance of biodiversity for ecosystem function (Figures 3 and 4). The Indian Sarus crane is a globally threatened species, its conflict with the farmer is increasing and this has led to decline in crane population at Gujarat. The breeding performance of Sarus crane is studied in the agricultural landscape of Western India (1996-98) and detailed records of 70 nests were maintained from egg laying till fledging. Farmers need to be educated and compensated for damage and to develop a viable formula for crane conservation [6,7].

Agro-ecosystems were initially regarded as degraded environments where the impact of human inferences is quite significant, resulting in a species poor landscapes. Avifauna structures of such landscape were hardly studied in many palaetropical countries. But Common Birds Census $(\mathrm{CBC})$ is important data source in the detection of long-term declines in many species of lowland farmland birds [8].

However, recent studies in both temperate and neotropical countries have shown that agro-ecosystem can be treated as a new ecological system which has its own distinctive biodiversity. Since

*Corresponding author: Narayan Ramappa Birasal, Associate Professor, Zoology Department, KLE Society's Gudleppa Hallikeri College, Haveri-581110, Karnataka, India. Tel: +91-9449122732; E-mail: nrbirasal@gmail.com

Received February 07, 2014; Accepted February 08, 2014; Published February 15,2014

Citation: Birasal NR (2014) Agricultural Ecosystem: An Encouraging Field for Ornithologists. J Biodivers Endanger Species 2: 119. doi: 10.4172/23322543.1000119

Copyright: (C) 2014 Birasal NR. This is an open-access article distributed under the terms of the Creative Commons Attribution License, which permits unrestricted use, distribution, and reproduction in any medium, provided the original author and source are credited. 


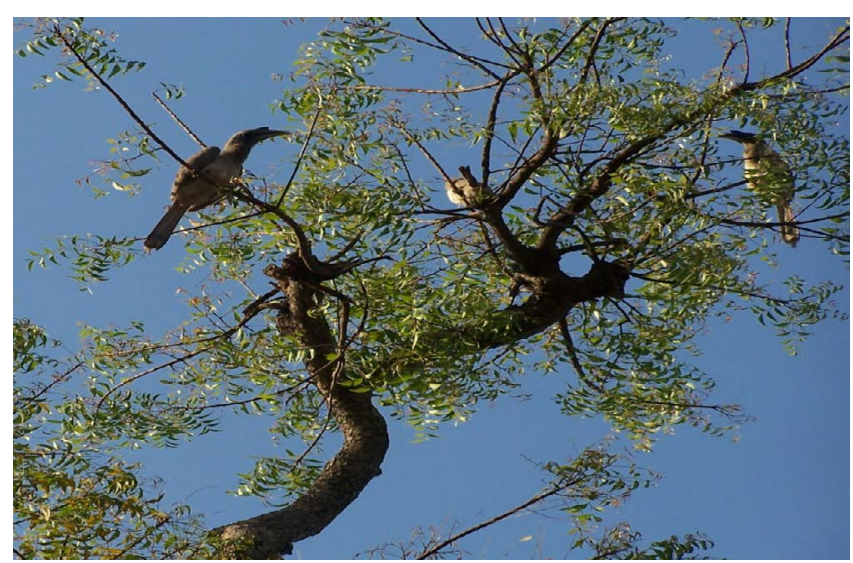

Figure 3: Grey hornbills found on the neem tree found in agricultural ecosystem.

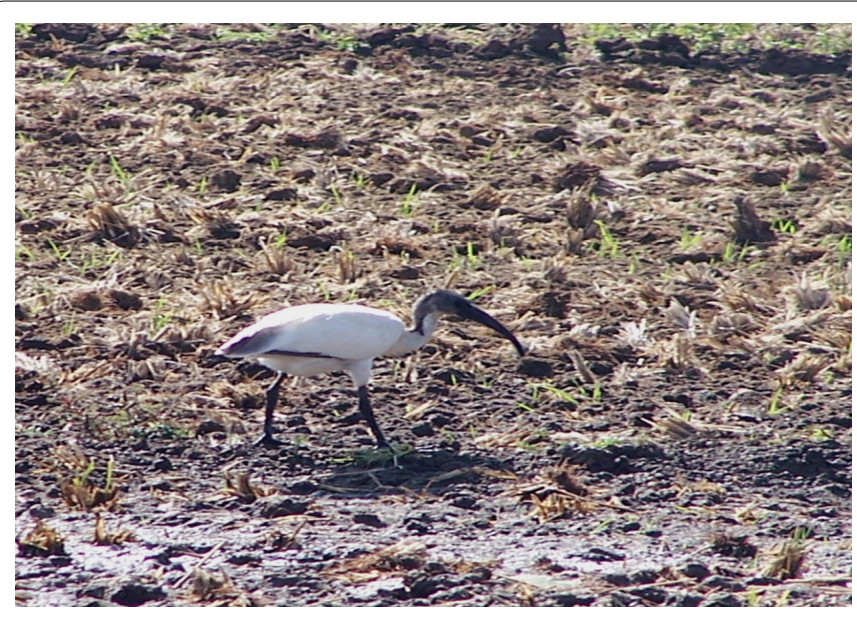

Figure 4: White ibis is searching for its food in the harvested paddy field.

agricultural landscape has been created and managed by humans, there is 'planned diversity'. $\mathrm{CBC}$ data is useful to examine habitat selection by Corn Buntings and the relationship between population change and land-use change at the scale of the individual farm [9].

India is an agrarian country with farmers making nearly $70 \%$ of the billion-plus population. The beginning of modern ornithology in India may be taken as dating from the advent of Jerdon's Birds of India in 1864 [10]. Birds are under pressure as the $21^{\text {st }}$ century attacks us with its silicon gods and an unfeeling, bizarre commitment to the totems of conquest [11]. One of the earliest accounts of Indian birds was published in 1713 by Buckley [12], an East India Company surgeon in Madras. The potentialities of research in economic ornithology in an agricultural country like India are unbounded [13]. Though agricultural bird problems in India are as old as agriculture itself, studies in agricultural ornithology and the other aspects of applied research were largely ignored until early eighties.

The individual agricultural ecosystems can be very different depending on the pedoclimatic characteristics of the territories, the types of cultivation practiced, and the intensive practices used, although in all cases, to maintain specific productive characteristics there is the need for human intervention. If they are abandoned to their natural evolution, these systems tend to recover their natural state, with increases in the areas occupied by spontaneous vegetation and with substantial changes in the population dynamics of the various species that make up the wild fauna and flora, obviously at the expense of the species that benefit from the human actions.

Use of cultivated areas as nesting habitat in Spain is the major determinant for the breeding success of Montagu's Harrier [14]. Birds are very important in agro-ecosystem as they are good indicator of agro-biodiversity. They are also known to play various important ecological functions in agricultural landscapes. As the maximization of crop yield is the major concern for all nowadays, birds in agricultural landscapes are generally viewed as 'pests' to a variety of crops. Foraging ecology of some Indian bird species has been studied in cultivated and natural habitats and one such significant study was on frugivores - Red vented bulbul [15].

However, there are many birds which are destroyers of insect pests and rodents, and hence they are beneficial to the crops and the farmers. Moreover, birds which damage crops (depredatory birds) may also play vital ecological functions in the agricultural landscapes as well as in other surrounding landscapes such as wetlands, urban or suburban and forested areas. In the recent past, the changes in agricultural management have resulted in increased crop and grass production. This intensification is accompanied by population declines among farmland bird species and a decline in farmland biodiversity [16].

The science of agricultural ornithology deals with obtaining scientific information on birds in relation to agriculture and using this information for the management of birds in agricultural landscape. Change in agricultural land-use may be responsible for contractions in range that have occurred in a number of bird species and this was examined in ranges of 21 farmland bird species in lowland England and Wales [17].

Studies on Agricultural ornithology were started in India in 1973 on the recommendation of renowned ornithologist Salim Ali. Since then, there has been a steady progress in the study on the role of birds in relation to crop production. Against this backdrop, goal of accommodating Red-winged blackbirds as part of the wetland agricultural complex in North America is commendable [18]. There are also reports on agricultural intensifications and the decline in population of farmland birds in Europe [19].

A number of need based bird management practices for increasing crop production have been developed for adoption by the farming community in the country. A total of 63 species of birds belonging to 19 families have been identified in damaging the crops. Detailed analysis of food and feeding behavior of insectivorous birds is fundamental to assess economic importance and information on this aspect on Indian birds is limited [20].

In spite of the progress achieved so far in the study on agricultural ornithology in India, data on depredatory birds, beneficial birds, role of birds in relation to crop yields, etc. from the agricultural landscapes in the eastern India and north-eastern region of the country are lacking. Post-independence ornithology in India seems to have failed to keep up with changes and advances elsewhere [21].

Moreover, farmland biodiversity forms an important part of the total biodiversity of the region. There is tremendous lack of knowledge on the agro-biodiversity of the region. Bird management in India should involve controlling the harmful species and encouraging the beneficial ones. For these, a proper understanding of the ecological requirements and economic status of the birds is required. It is reported that the loss of grassland habitat and agricultural intensification has resulted in reduced nest success [22]. 
In India, the science of agricultural ornithology is still in its infancy. Though research in this field has been started in various parts of the country, there appears to be a huge gap in knowledge, information and research on agricultural birds of the northeast India. It is cautioned that agricultural intensification accelerated as a result of Common Agricultural Policy (CAP) is resulting in declining biodiversity in agricultural landscapes [23].

Thus, agricultural landscape represent as a laboratory for studying a new aspects of biodiversity - impact of human activities on (avian) biodiversity and importance of habitat heterogeneity in maintaining biodiversity. Studies in Europe and North America show that habitat heterogeneity is associated with higher biodiversity in the farmed landscape.

Habitat heterogeneity has been implicated as a key to improving and conserving biodiversity. Recent studies by the authors show the importance of habitat heterogeneity in improving certain landscapes such as wetlands, urban landscapes, etc. Now the researchers are making an attempt to present the pattern of matter and energy flow in a most common species of bird - House sparrow [24].

Birds are not a new problem as regards to agricultural crop damage. References to damages caused by birds have been made periodically during the last five centuries. The havoc played by them has led to the enactment of laws for their control in Britain since fifteenth century. Our journal 'Biodiversity and Endangered species' appeal academicians and researchers to send their original research articles, comments, observations, notes and reviews on the agro-ecosystem and the bird species activities in the respective locality.

\section{References}

1. Manjit SD, Harjeet KS (1994) Agricultural ornithology : an Indian perspective. J Biosci 19: 391-402.

2. Borad CK, Mukherjee A, Patel SB, Parasharya BM (2002) Breeding performance of Indian Sarus crane Grus antigone antigone in the paddy crop agroecosystem. Biodiversity and conservation 11: 795-805.

3. Parasharya BM, Dodia JF, Mathew KL, Yadav DN (1994) Natural regulation of white grub (Holotrichia sp: Scarabidae) by birds in agroecosystem. J Biosci 19: $381-389$

4. Sparks TH, Parish T, Hinsley SA (1996) Breeding birds in field boundaries in an agricultural landscape. Agriculture, ecosystems and environment 60: 1-8.

5. Siriwardena GM, Crick HQP, Baillie SR, Wilson JD (2000) Agricultural habitattype and the breeding performance of granivorous farmland birds in Britain Bird study 47: 66-81.

6. Borad C K, Mukherjee A, Parasharya BM (2001) Damage potential of Indian Sarus crane in paddy crop agroecosystem in Kheda district, Gujarat, India. Agriculture, ecosystems and environment $86: 211-215$
7. Mukherjee A, Borad CK, Parasharya BM (2002) Breeding performance of the Indian Sarus crane in the agricultural landscape of western India. Biol Conserv 105: 263-269.

8. Chamberlain DE, Fuller RJ, Garthwaite DG, Impey AJ (2001) A comparison of farmland bird density and species richness in lowland England between two periods of contrasting agricultural practice. Bird study 48: 245-251.

9. Donald PF, Forrest C (1995) The effects of agricultural change on population size of Corn Buntings Miliaria calandra on individual farms. Bird study 42: 205-215.

10. Salim Ali (1971) Ornithology in India: Its past, present and future. Proc Indian Natl Sci Acad B 37: 99-112.

11. Pritish Nandy (1985) In search of the mountain quail. The illustrated weekly of India 8-17.

12. Salim Ali (1979) Bird study in India: Its history and its importance. Indian Council for Cultural Relations, New Delhi, India.

13. Salim Ali (1936) Economic ornithology in India. Current science : 472-478

14. Corbacho C, Sanchez JM, Sanchez A (1997) Breeding biology of Montagu's Harrier Cirus pygargus L. in agricultural environments of southwest Spain comparison with other populations in the western Palearctic. Bird study 44 166-175.

15. Dinesh Bhatt and Anil Kumar (2001) Foraging ecology of Red-vented Bulbu Pycnonotus cafer in Haridwar, India. Forktail 17: 109-110.

16. Chamberlain DE, Fuller RJ, Bunce RGH, Duckworth JC, Shrubb M (2000) Change in the abundance of farmland birds in relation to the timing of agricultural intensification in England and Wales. J Appl Ecol 37: 771-788.

17. Chamberlain DE, Fuller RJ (2000) Local extinctions and changes in species richness of lowland farmland birds in England and Wales in relation to recent changes in agricultural land-use. Agriculture, ecosystems and environment 78 : $1-17$.

18. Dolbeer RA (1990) Ornithology and integrated pest management: Red-winged Blackbirds Agelaius phoeniceus and corn. Ibis 132: 309-322.

19. Donal PF, Green RE, Heath MF (2001) Agricultural intensification and the collapse of Europe's farmland bird populations. Proc Biol sci 268: 25-29.

20. Asokan S, Mohamed A, Samsoor A, Manikannan R (2009) Diet of three insectivorous birds in Nagapattinam district, Tamil Nadu, India-a preliminary study. Journal of Threatened Taxa 1: 327-330.

21. Shyamal L (2007) Opinion: Taking Indian ornithology into the information age. Indian Birds 3: 122-137.

22. Jeffery WW, Eric LK, Richard EW (2006) Low Nesting Success of Loggerhead Shrikes in an Agricultural Landscape. The Wilson Journal of ornithology 118 70-74.

23. Berendse F, Chamberian D, Kleijn D, Schekkerman $H$ (2004) Declining biodiversity in agricultural landscapes and the effectiveness of Agri-environment schemes. Ambio: A journal of the Human environment 33: 499-502.

24. Mukerjee A, Wilske B, Borad CK (2007) The Role of Birds In Matter And Energy Flow In The Ecosystem. The raffles bulletin of zoology 55: 191-194. 